\title{
Effectiveness of Minor Overhaul Elimination on Decreasing Cost of Production in Hydroelectric Power Plant
}

\section{Pengaruh Eliminasi Minor Overhaul Terhadap Penurunan Biaya Pokok Penyediaan Pada PLTA Dengan Metode Markov Chain Melalui Laravel}

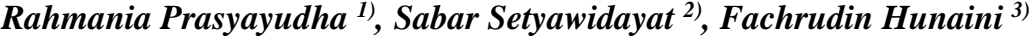 \\ ${ }^{1,2,3)}$ Electrical Engineering, Widyagama University Malang, Indonesia \\ 1)yudhakaien@gmail.com \\ 2) sabarset@yahoo.com \\ 3)
}

\begin{abstract}
The projection of the renewable energy target in 2025 is $23 \%$. The high production cost makes it difficult to compete with fossil plants. The strategy chosen to reduce the risk is to eliminate minor overhauls in power plants to increase production. To prove its effectiveness, hydropower was chosen by using markov chain method. It took samples for 26 months and divided plant into 3 states based on the operating performance. The test was between implementation of overhauls on schedule and eliminating minor overhauls when the status was good. The results of data processing obtained that the best decision is not to do minor overhaul elimination because of the potential to reduce $29.77 \%$ good conditions, $30.69 \%$ improvement in moderate conditions. Comparison between the 2017-2019 data show there's no production cost reduction even though potential production increase. Calculation can be implemented into a web form using the PHP on the Laravel Framework.
\end{abstract}

Keywords : Production Cost; Overhaul; Markov Chain.

\begin{abstract}
Abstrak-. Proyeksi target bauran energi baru terbarukan tahun 2025 sebesar 23\% berbanding terbalik dengan total pemanfaatannya. Tingginya biaya pokok penyediaan menyebabkan pembangkit energi terbarukan sulit bersaing dengan pembangkit fosil. Strategi yang dipilih untuk menurunkan biaya pokok penyediaan adalah melakukan eliminasi minor overhaul pada pembangkit untuk meningkatkan produksi. Pembuktian efektifitas kebijakan diterapkan pada pembangkit listrik tenaga air sebagai komponen terbesar energi baru terbarukan dengan metode markov chain. Penelitian menggunakan sampel selama 26 bulan dan membagi pembangkit menjadi 3 status berdasarkan capaian kinerja operasi. Kebijakan yang diuji adalah pelaksaan overhaul sesuai jadwal dibanding eliminasi minor overhaul saat status baik. Hasil pengolahan data didapat keputusan terbaik adalah tidak melakukan eliminasi minor overhaul karena berpotensi menurunkan kondisi baik $29.77 \%$, peningkatan kondisi sedang 30.69\%. Hasil perbandingan terhadap data 2017-2019 tidak terjadi penurunan biaya pokok penyediaan meskipun terdapat potensi peningkatan produksi. Proses perhitungan dapat diimplementasikan menjadi bentuk web dengan bahasa PHP pada framework Laravel.
\end{abstract}

Kata Kunci : Biaya Pokok Penyediaan; Overhaul; Markov Chain. 


\section{PENDAHULUAN}

Peraturan Pemerintah No.79 Tahun 2014 tentang Kebijakan Energi Nasional menyebutkan target bauran energi baru dan terbarukan pada tahun 2025 adalah $23 \%$ dan $31 \%$ pada tahun 2050 [1]. Berbanding terbalik dengan proyeksi pertumbuhan yang meningkat, pemanfaatan energi baru terbarukan (EBT) untuk ketenagalistrikan masih rendah disebabkan masih tingginya Biaya Pokok Penyediaan pembangkit EBT sehingga sulit bersaing dengan pembangkit fosil terutama batubara yang tidak memperhitungkan biaya eksternalitas. Biaya Pokok Penyediaan (BPP) adalah biaya penyediaan listrik oleh PT.PLN (Persero) untuk melaksanakan kegiatan operasi di pembangkitan, penyaluran (transmisi), dan pendistribusian tenaga listrik ke pelanggan dibagi dengan total kwh jual [2]. Strategi BPP pada pembangkit listrik tenaga air (PLTA) diterapan dengan melakukan eliminasi overhaul pada scope minornya. Opsi ini dipilih karena dianggap memiliki pengaruh yang signifikan dalam penurunan BPP. Penelitian mengenai perhitungan harga yang kompetitif dan pemilihan alternative dalam penentuan komponen biaya dijelaskan oleh William G. Sullivan , Elin M.Wicks dan Patick Koelling dalam bukunya mengenai pentingnya penyelesaian masalah yang berfokus tidak hanya pada produk, sistem dan proses tetapi tetap memperhitungakan potensi penghematan yang diperoleh [3] didukung dengan penelitian yang dilakukan oleh Andri Swasono, Fachrudin Hunaini dan Dedi Usman dalam penelitian mereka yang menjelaskan pentingnya perhitungan cost energy untuk menurunkan BPP dan cost investment [4]. Perhitungan mengenai Biaya Pokok Penyediaan listrik dilakukan oleh Dodi Perdana Putra [5], Uliana Arta dan Juanda Astrani [6] penelitian mereka menjelaskan mengenai pentingnya perhitungan BPP listrik karena berhubungan dengan kebijakan penentuan tarif dan pelayanan kepada masyarakat.

Metode yang digunakan untuk mengetahui efektifitas strategi yang dipilih adalah menggunakan metode markov chain. Penelitiaan mengenai penggunaan metode markov chain dalam pengambilan keputusan perusahaan sebelumnya dilakukan oleh Rudi Tri Hartanto [7], M. Hartono dan Mas'udin [8] digunakan untuk menghitung probabilitas pemeliharaan mesin menjelaskan bahwa perhitungan dengan menggunakan metode markov chain sangat cocok dipilih karena tidak tergantung lama proses dimasa lalu, tetapi perhitungan berdasar state sekarang. Analisis yang dihasilkan akan menunjukkan pengaruh keputusan melakukan eliminasi overhaul yang telah dilaksanakan tepat atau dapat menggunakan alternative lain.

Dalam penelitian ini data sampel akan diolah dengan metode markov chain sehingga didapat hasil perhitungan yang akurat kemudian akan diimplementasikan dalam web Laravel dengan Bahasa permograman berformat php. Format php dipilih karena php merupakan Bahasa pemrograman yang dapat dijalankan pada berbagai platform dan kompatibel terhadap hamper semua server yang digunakan saat ini, bebas diunduh dari situs resmi php dan berjalan efisien pada sisi server [9] Perhitungan dengan menggunakan metode markov chain yang rumit dapat dirubah menjadi format sederhana dengan tampilan visual yang mudah dipahami.

\section{II.TINJAUAN PUSTAKA}

\subsection{Overhaul}

Overhaul merupakan salah satu usaha pemeliharaan unit pembangkit yang diharapkan dapat memberikan kontribusi yang optimal guna keandalan dan efisiensi sampai periode berikutnya (siklus overhaul). Untuk itu sangat diperlukan usaha - usaha guna mendapatkan hasil pelaksanaan overhaul yang memenuhi sasaran unit pembangkit [10].

Kegiatan overhaul meliputi tahapan kerja mulai dari perencanaan, pelaksanaan, pengendalian, dan evaluasi pekerjaan pemeliharaan suatu alat/mesin/instalasi/jaringan dan lain lain. Tujuannya agar unit dapat beroperasi dengan handal (reliability), aman (safe), siap (avaibility) yang tinggi serta unjuk kerja yang baik sesuai dengan umur peralatan dan dengan waktu pemeliharaan yang efektif dan biaya yang efisien dan ekonomis. Berikut contoh jadwal dalam satu siklus overhaul.

[Table 1 about here.]

Pada table 1, pemeliharaan yang dilakukan di unit PLTA adalah:

1) Annual Inspection (AI) : Pemeliharaan yang dilakukan hanya memeriksa alat bantu utama dan dilakukan setiap 8000 jam.

2) General Inspection (GI) : Pemeliharaan yang dilakukan dengan membuka bearing, casing turbine, serta seluruh peralatan bantu. Dilakukan setiap 20.000 jam.

3) Major Overhaul (MO) : Pemeliharaan yang dilakukan dengan memeriksa peralatan utama (turbine, bearing, shaft, generator) serta peralatan bantunya, dan dilakukan setiap 40.000 jam.

\subsection{Kinerja Operasi dan Biaya Pokok Penyediaan}

Dalam pelaksanaan pemenuhan kebutuhan sistem operasi, seluruh unit pembangkit memiliki target operasinya masing masing. Target kinerja operasi ini kemudian digunakan untuk mengukur performa dari tiap tiap unit pembangkit dan menjadi dasar dalam pengoperasian unit pembangkit.

1) Target Produksi : Berisi besar daya yang diproduksi suatu unit pembangkit selama 1 tahun anggaran (GWh). Polaritas pencapaiannya adalah positif, yaitu semakin naik semakin baik.

2) Target Penjualan : Berisi besar daya yang disalurkan oleh sutau unit pembangkit pada jaringan sistem operasi selama 1 tahun anggaran $(\mathrm{GWh})$. Polaritas pencapaiannya adalah positif, yaitu semakin naik semakin baik.

3) Pemakaian Sendiri (PS) : Jumlah KWh pemakaian sendiri dibagi total KWh produksi bruto pembangkit dalam 
satuan persen (\%). Polaritas pencapaiannya negative yaitu lebih rendah lebih baik.

4) Equivalent Availability Factor (EAF) : Faktor kesiapan mesin pembangkit untuk beroperasi pada DMN dalam satuan persen (\%). EAF dalam sebuah unit pembangkit dihitung dengan formula :

$$
E A F=\frac{\sum_{i=1}^{n}\{A H-(E F D H+E M D H+E P D H+E S E D H)}{\sum_{i=1}^{n} P H} \times 100 \%(1)
$$

Dimana :

i : Jumlah unit pembangkit

AH : Availabe Hours

EFDH : Equivalent Forced Derated Hours

EMDH : Equivalent Maintenance Derated Hours

EPDH : Equivalent Planned Derated Hours

ESEDH : Equivalent Seasonal Derated Hours

$\mathrm{PH} \quad$ : Period Hours

5) Equivalent Forced Otage Factor (EFOR) : Presentase jam gangguan dan jam derating yang tidak direncanakan terhadap jumlah jam pelayanan pembangkit dalam satu periode ditanyakan dalam satuan persen (\%). EFOR memiliki polaritas negative, sehingga semakin rendah pencapaian maka semakin baik.

6) Sudden Outage Factor (SdOF) : Jumlah gangguan mendadak yang terjadi pada suatu unit pembangkit sehingga menyebabkan unit tidak siap operasi. SdOF dinyatakan dalam satuan kali/unit. SdOF memiliki polaritas negatif, sehingga semakin rendah pencapaian maka semakin baik.

7) Scheduled Outage Factor (SOF) : Rasio dari jumlah jam unit pembangkit keluar terencana dari jaringan operasi sistem (planned outage dan maintenance outage) terhadap jumlah jam dalam 1 periode.

8) Air Limpas : Air limpas dihitung ketika air melimpas melalui spill way dalam satuan kali (x). Penilaian terhadap kinerja ini dengan mempertimbangkan status kesiapan unit dan action plan dari pihak terkait.

Biaya Pokok Penyediaan listrik adalah biaya barang yang telah diselesaikan selama satu periode disebut juga harga pokok produksi barang selesai (cost of good manucfatured) [11]. Penentuan biaya pokok penyediaan listrik pada pembangkit listrik terbentuk harga Rp/komponen biaya. Dalam hal ini komponen biaya yang dimaksud adalah komponan ABCD. Komponen $\mathrm{ABCD}$ dibentuk dengan perhitungan komponen biaya tetap berdasarkan kapasitas :

1) Komponen A (Capital Cost Recovery). Merupakan pengembalian atas biaya kapital/modal yang ditanamkan dalam pembanungan pusat pembangkit.

2) Komponen B (Fixed Cost Operation and Maintenance / O\&M). Merupakan biaya yang harus dibayarkan/dikeluarkan dengan tidak melihat apakah unit pembangkit tersebut beroperasi menghasilkan produksi energi/tidak.

3) Komponen $\mathrm{C}$ (Variable Cost). Merupakan penggantian atas biaya bahan bakar yang digunakan dalam memproduksi energi listrik. Harga dan perlakuan untuk energi primer/bahan bakar yang digunakan oleh pembangkit berbeda satu sama lain tergantung ada kesepakatan. Pada PLTA biaya ini adalah biaya pemakaian air.

\subsection{Analisis Markov Chain}

Markov chain adalah suatu metode yang mempelajari sifat-sifat suatu variabel pada masa sekarang yang didasarkan pada sifat-sifatnya dimasa lalu dalam usaha menaksir sifat-sifat variabel tersebut di masa yang akan datang [8]. Secara umum suatu proses markov chain adalah proses stokastik dimana setiap variable random $X_{t}$ hanya tergantung pada variabel yang mendahuluinya yaitu $X_{(t-1)}$ dan hanya mempengaruhi variable random berikutnya yaitu $\mathrm{X}_{(\mathrm{t}+1)}$. Sehingga istilah chain disini menyatakan kaitan antara variable yang saling berdekatan. Perhitungan probabilitas dengan menggunakan analisis Markov dilakukan dengan menentukan rancangan pengamatan. Rancangan pengamatan kemudian menjadi dasar dalam perhitungan probabilitas. Probabilitas dapat dihitung dengan menggunakan rumus:

$$
P_{i j}=\frac{m_{i j}}{m_{i}}
$$

Dimana :

$\mathrm{P}_{\mathrm{ij}} \quad$ : Probabilitas

$\mathrm{M}_{\mathrm{ij}} \quad$ : Keadaan system pada status-j

$\mathrm{M}_{\mathrm{i}} \quad$ : Banyaknya/jumlah system pada status-j [8]

Hasil dari rancangan probabilitas tiap tiap status atau keputusan kemudian diolah kembali untuk menentukan keputusan rantai markov chainnya. Analisis keputusan dibagi menjadi 2 yaitu finite stage dan infinite stage. Finite stage dibatasi iterasi dan stagenya. Model ini digunakan pada persoalan mengenai perbaikan mesin, si pengambil keputusan dari persoalan perbaikan mesin tersebut merencanakan akan menghentikan pengoperasian mesin itu dalam $n$ bulan. Maka stagenya dibatasi selama $n$ bulan masa pengoperasian mesin berhenti. Menghitung nilai pada masing masing stage digunakan persamaan:

$$
v i^{k}=\sum_{j=1} p i j^{k} r i j^{k}
$$

Dimana :

$\mathrm{Vi}^{\mathrm{k}}=$ Ekspektasi yang didapatkan dari suau transisi tunggal

dari state-i pada suatu status $\mathrm{k}$

$\mathrm{P} \quad=$ Probabilitas

$\mathrm{i} \quad=$ State status saat ini

$\mathrm{j} \quad=$ State status periode berikutnya

Sedangkan untuk perhitungan pada stage terakhir digunakan persamaan:

$$
f n^{(i)}=\max _{k}\left\{v i^{k}+\sum_{j=1} p i j^{k} f n+1(j)\right\}(4)
$$


Dimana :

$\mathrm{k}=$ Status perlakuan

$\mathrm{fn}^{(\mathrm{i})}=$ Fungsi pada stage $-\mathrm{n}$ dengan status mesin saat ini

Infinite stage digunakan dalam perhitungan dengan lingkup long run atau perhitungan pada sistem yang dibutuhkan untuk mencapai status stabil (steady stage) dengan iterasi tidak terbatas. Metode yang digunakan pada perhitungan ini antara lain metode enumerasi sempurna, yang digunakan apabila jumlah total stationary policy tidak terlalu besar dan metode policy iteration yang mampu mengurangi kesulitan perhitungan pada metode pertama [12].

\subsection{Laravel Framework}

Framework adalah seperangkat struktur dan pedoman konseptual yang digunakan untuk membangun suatu bermanfaat. Laravel adalah salah satu framework PHP yang banyak digunakan dalam pembangunan program web. Laravel menggunakan struktur MVC (Model View Controller) yaitu program yang dapat memisahkan data dari tampilan berdasarkan komponen - komponen program. Struktur MVC membuat Laravel mudah dipelajari.

\section{METODE}

Metode penelitian yang dilakukan meliputi tahapan antara lain : pengumpulan data, penetapan klasifikasi untuk perhitungan markov chain, perhitungan markov chain melalui web Laravel, dan analisis hasil perhitungan. Data sampel yang digunakan berasal dari realisasi pencapaian kinerja operasi dan pencapaian BPP dalam kurun waktu 1 periode penelitian. Proses pengerjaan skripsi menggunakan metode markov chain sebagai dasar perhitungan probabilitas dan pengambilan keputusan yang selanjutnya diimplementasikan pada web Laravel dengan Bahasa pemrograman PHP.

\subsection{Data Perhitungan Markov Chain}

1) Data kinerja produksi pembangkit pada PLTA dikelompokkan menjadi 3 status yaitu baik, sedang dan berat. Klasifikasi usulan status dapat dilihat pada tabel 2.

\section{[Table 2 about here.]}

2) Penetapan usulan kebijakan memungkinkan perusahaan untuk mendapatkan hasil yang berbeda dari kebijakan baru yang dibuat. Penetapan usulan kebijakan menjadi pembanding atas kebijakan yang dilakukan perusahaan. Usulan kebijakan yang dibandingkan adalah :

a) Kebijakan 1 : Dilakukan inspeksi pada seluruh status.

b) Kebijakan 2 : Dilakukan inspeksi pada status 3 dan 2 . Tidak dilakukan inspeksi pada status 1.

\subsection{Perhitungan Probabilitas}

10.21070/jeeeu.v5i1.1228

Probabilitas menunjukkan kemungkinan terjadinya suatu peristiwa yang bersifat acak. Nilai probabilitas terkecil adalah 0 yang berarti bahwa peristiwa yang tidak mungkin terjadi [13]. Variabel yang sudah ditentukan pada table 3.1 digunakan sebagai dasar penetapan matrix probabilitas transisi status unit pembangkit dan probabilitas transisi produksi pembangkit..

1) Rekapitulasi pembangkit saat dilakukan kebijakan 1 dan 2. Berikut contoh tabel hasil rekapitulasi perubahan status pembangkit saat dilakukan kebijakan 1 dan 2 untuk PLTA Ampelgading unit 1.

\section{[Table 3 about here.]}

Tabel 3 Rekapitulasi perubahan status pembangkit PLTA Ampelgading unit 1 saat dilakukan kebijakan 2

[Table 4 about here.]

Tabel 4 digunakan sebagai database sedangkan table 3 digunakan sebagai input pada software.

2) Rekapitulasi produksi pada kebijakan 1 dan kebijakan 2. Perhitungan dilakukan dari perhitungan rata-rata produksi pada 1 periode dikurangi rata-rata produksi yang hilang selama waktu perawatan. Periode perhitungan adalah 1 periode $(26$ bulan $=2.28$ tahun). Penentuan rekapitulasi produksi juga mempertimbangkan status unit pembangkit. Berikut hasil rekapitulasi produksi PLTA Ampelgading unit 1.

\section{[Table 5 about here.]}

Rekapitulasi produksi pembangkit saat dilakukan kebijakan 2 dihitung dari presentase perubahan produksi saat terjadi gangguan pada unit pembangkit sesuai dengan klasifikasi kerusakan yang dialami [14]. Presentase perubahan produksi yang terjadi pada pembangkit saat dilakukan eliminasi minor overhaul dihitung berdasarkan kemungkinan derating yang terjadi pada masing - masing status [15]. Berikut hasil rekapitulasi produksi PLTA Ampelgading unit 1 saat dilakukan kebijakan 2.

\section{[Table 6 about here.]}

3) Penentuan jumlah stage. Penentuan jumlah stage digunakan untuk menunjukkan lama periode metode perhitungan dapat digunakan. Perhitungan markov pada penelitian ini menggunakan metode finite stage dengan jumlah 2 stage dengan pertimbangan setiap 20.000 jam atau pada stage ke 3 unit akan dilakukan general inspection.

\subsection{Diagram Alir Program}

Diagram alir dari software yang dikembangkan sebagaimana ditunjukkan oleh gambar 1. Langkah awal dalam 
pemrograman adalah memasukkan data status pembangkit dan produksi pembangkit, selanjutnya software melakukan pembacaan data dan melakukan perhitungan probabilitas dan probabilitas transisi dari data input. Data kemudian diolah menggunakan metode markov chain dengan 2 stage seperti pada persamaan 2.3 dan persamaan 2.4. Hasil akhir dari software akan menunjukkan tindakan terbaik dan produksi maksimal dari masing masing stage untuk tiap unit pembangkit yang dipilih.

[Figure 1 about here.]

\section{HASIL DAN PEMBAHASAN}

\subsection{Perhitungan Matrix Probabilitas Transisi Status}

Perhitungan matrix dilakukan dengan menggunakan data pada tabel 3.2, tabel 3.3, tabel 3.4 dan tabel 3.5 menggunakan persamaan 2.2. Perhitungan ini berlaku untuk kebijakan 1 dan kebijakan 2 untuk seluruh status. Data perhitungan menjadi data uji pada program. Data tersebut direkap dengan menggunakan file ekstensi *.CSV.

[Figure 2 about here.]

\subsection{Perhitungan Markovian 2 Stages}

Langkah perhitungan markov dilakukan dengan menggunakan persamaan 3 dan persamaan 4. Hasil perhitungan akan dibandingkan untuk memperoleh produksi optimal pada status baik untuk kebijakan 1 dan kebijakan 2.

[Figure 3 about here.]

[Figure 4 about here.]

4.3 Perbandingan Biaya Pokok Penyediaan Hasil Kebijakan Markov dengan Biaya Pokok Penyediaan Aktual

Hasil yang didapat dari perhitungan markov chain pada program, kemudian dibandingkan dengan hasil perhitungan aktual yang dicapai unit PLTA pada periode waktu yang sama. Nilai produksi maksimal yang ada pada program adalah nilai produksi untuk 1 periode (26 bulan). Capaian BPP yang dibandingkan dilakukan dalam waktu 1 tahun, maka terlebih dahulu dicari capaian produksi maksimal selama 1 tahun.

\section{[Table 7 about here.]}

Hasil perbandingan produksi digunakan untuk perhitungan capaian Biaya Pokok Penyediaan. Dengan asumsi biaya operasi (kepegawaian, administrasi, pemeliharaan) dan penyusutan sama, maka Biaya Pokok Penyediaan untuk hitungan markov chain dapat dihitung.

[Table 8 about here.]

[Figure 5 about here.]

\subsection{Analisis Tabel dan Grafik}

Analisis dilakukan terhadap 2 hasil perhitungan yaitu produksi dan biaya pokok penyediaan pada tabel 7 dan 8 serta grafik 5 Hasil analisis sebagai berikut :

1. Perbandingan antara capaian produksi hasil perbandingan markov dengan produksi aktual tahun 2018 dan 2019 didapat hasil capaian produksi markov lebih tinggi. Total produksi 2018 adalah 1.114.913 MWh, total produksi 2019 adalah 951.337 MWh sedangkan produksi markov sebesar 1.303.762 MWh. Sehingga potensi produksi yang dapat diraih sebesar 118.849 MWh untuk 2018 dan 352.425 MWh untuk 2019.

2. Anomali terjadi pada tahun 2019, untuk PLTA selain Ampelgading, Wonorejo dan Siman capaian produksi hasil perhitungan markov lebih kecil dibandingkan dengan produksi aktual PLTA.

3. Perbandingan BPP dan Produksi Markov pada tahun 2019, didapatkan produksi markov > produksi 2019 kecuali PLTA Siman dan Mendalan. Tapi tidak terjadi penurunan BPP pada PLTA dengan cpaaian produksi lebih tinggi. Potensi penurunan BPP terjadi pada PLTA Ngebel (potensi penurunan BPP $303 \mathrm{Rp} / \mathrm{Kwh})$, PLTA Sutami (30 Rp/Kwh), PLTA Tulungagung (138 Rp/KWh). PLTA Wlingi (91 Rp/Kwh), dan PLTA Wonorejo (188 Rp/KWh).

4. Perbandingan BPP dan Produksi Markov pada tahun 2018 didapatkan capaian produksi markov > produksi 2018 kecuali PLTA Siman dan Mendalan. Capaian BPP markov dibanding BPP aktual mengikuti capaian produksi. Anomali terjadi pada PLTA Golang dan Giringan, capaian produksi markov > produksi aktual tetapi tidak terjadi penurunan BPP.

5. Perbandingan BPP dan Produksi Markov pada tahun 2017. Capaian produksi markov < capaian aktual produksi 2017. Anomali terjadi pada PLTA Ampelgading dan Wonorejo. Capaian BPP mengikuti capaian produksi, anomali terjadi pada PLTA Lodoyo, PLTA Ngebel, PLTA Sengguruh, dan PLTA Tulungagung. Hasil perhitungan BPP Markov < BPP aktual sedang produksinya lebih kecil.

Analisis juga dilakukan mengenai perubahan status unit pembangkit saat dilakukan kebijakan 2. Analisis yag diperoleh sebagai berikut :

1) Saat dilakukan kebijakan 2, unit mengalami kemungkinan unit pembangkit dalam status berat menurun dari $1.59 \%$ saat dilakukan kebijakan 1 menjadi $0.66 \%$ saat dilakukan kebijakan 2.

a. Status baik mengalami penurunan sebesar $29.77 \%$ dari $80.56 \%$ pada saat dilakukan kebijakan 1 menjadi $50.79 \%$ saat dilakukan kebijakan 2 penurunan. Status berbeda terjadi pada status sedang yang mengalami peningkatan sebesar $30.69 \%$ dari $17.86 \%$ menjadi $48.54 \%$ saat dilakukan kebijakan 2 . 


\section{KESIMPULAN}

Berdasarkan hasil pengujian dan analisis hasil perhitungan menggunakan software, maka dapat disimpulkan bahwa kebijakan terbaik yang dapat digunakan perusahaan adalah kebijakan 1. Penurunan bpp karena peningkatan produksi hanya terjadi pada PLTA Sutami, Wlingi dan Wonorejo sedangkan PLTA yang lain terjadi anomali. Potensi kerusakan juga membesar didukung penurunan status baik dari $80.56 \%$ jika dilakukan kebijakan 1 menjadi $50.79 \%$ jika dilakukan kebijakan 2. Perhitungan metode markov dapat diimplementasikan pada software Laravel.

\section{REFERENSI}

[1] Anonymous, "Outlook Energi Indonesia 2017," Sekr Jendral Dewan Energi Nas., 2017.

[2] Anonymous, "Peraturan Menteri Keuangan Nomor: 117/PMK.02/2005 Tentang Tata Cara Penghitungan dan Pembayaran Subsidii Listrik Tahun Anggaran 2005." Menteri Keuangan Republik Indonesia, 2005.

[3] W. G. Sullivan, E. M. Wicks, and C. P. Koelling, Engineering Economy. Pearson Education, 2014.

[4] A. Swasono, F. Hunaini, and D. U. Effendy, "Perancangan Aplikasi Perbandingan Biaya Energi Pada Industri Berbasis Netbeans," J. Widya Tek., vol. 26, Oktober 2018.

[5] D. Perdana Putra, "Perhitungan Harga Pokok Produksi Listrik pada PT PLN Batam.” Politeknik Negeri Batam, 2011.

[6] J. Astarani and A. Uliana, "Analisis Penentuan Biaya Produksi Listrik Dengan Metode Full Costing Pada PT. PLN (Persero) Wilayah Kalimantan Barat Area Pontianak," J. AAKFE, vol. 2, no. 1, pp. 1-30, Agustus 2013.

[7] R. Tri Hartanto, "Perencanaan Pemeliharaan Mesin Pompa Gilingan Saus dengan Metode Markov Chain untuk Minimasi Biaya Pemeliharaan." Universitas Muhammadiyah Surakarta, 2014.

[8] M. Hartono and I. Mas'udin, "Perencanaan Perawatan Mesin Dengan Metode Markov Chain Guna Menurunkan Biaya Perawatan," J. Oprimumm, vol. 3, no. 2, pp. 173184, 2002.

[9] Erawan, Dasar - Dasar PHP. Universitas Dian Nuswantoro Semarang, 2014.

[10] A. Y. Suparman, Overhaul berbasis 5S. PT PJB, 2014.

[11] C. Anwar, L. Fasi Ashari, and Indrayenti, "Harga Pokok Produksi dalam Kaitannya dengan Penentuan Harga Jual untuk Pencapaian Target Laba Analisis (Studi kasus pada
PT. Indra 10.21070/jeeeu.v5i1.1228

Keuang., vol. 1, no. 1, pp. 79-94, Sep. 2010.

[12] Oktaviyani, “Optimasi Penjadwalan Produksi dan Perencanaan Persediaan Bahan Baku Menggunakan Rantai Markov (Studi Kasus Kinken Cake \& Bakery Kutoarjo).” 2017.

[13] Syafruddin, Irma, and Sukarna, “Aplikasi Analisis Rantai Markov untuk Memprediksi Status Pasien Rumah Sakit Umum Daerah Kabupaten Barru," Online J. Nat. Sci., vol. 3, no. 3, Desember 2014.

[14] N. Erni and B. Wijaya, "Usulan Penerapan Teori Markov Dalam Pengambilan Keputusan Perawatan Tahunan Pada PT.Pupuk Kujang,” J. Inovisi, vol. 7, no. 1, pp. 56-63, Oktober 2011.

[15] Anonymous, Maintenance Planning, Scheduling \& Controlling. PT PJB Academy, 2015.

Conflict of Interest Statement: The author declares that the research was conducted in the absence of any commercial or financial relationships that could be construed as a potential conflict of interest.

Copyright (C) 2021 Author [s]. This is an open access article distributed under the terms of the Creative Commons Attribution License (CC BY). The use, distribution or reproduction in other forums is permitted, provided the original author(s) and the copyright owner(s) are credited and that the original publication in this journal is cited, in accordance with accepted academic practice. No use, distribution or reproduction is permitted which does not comply with these terms.

Received: 2021-01-30

Accepted: 2021-02-06

Published: 2021-04-01 


\section{DAFTAR TABEL}

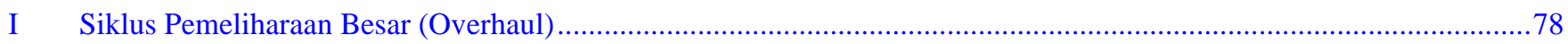

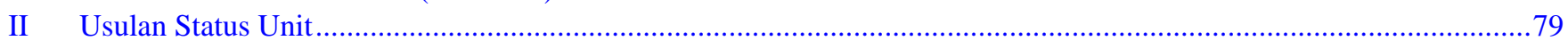

III Rekapitulasi Perubahan Status Pembangkit PLTA Ampelgading Unit 1 Saat Dilukan Kebijakan 1 ............................80

IV Rekapitulasi perubahan status pembangkit PLTA Ampelgading unit 1 saat dilakukan kebijakan 2 .............................8 81

V Rekapitulasi produksi pembangkit PLTA Ampelgading unit 1 saat dilakukan kebijakan 1 ....................................82

VI Rekapitulasi produksi pembangkit PLTA Ampelgading unit 1 saat dilakukan kebijakan 2 ..................................8

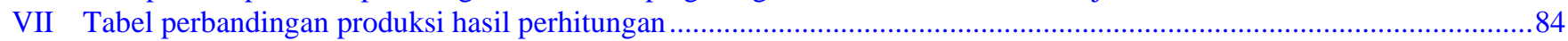

VIII Perbandingan Capaian Biaya Pokok Penyediaan Markov vs Capaian Biaya Pokok Penyediaan Aktual .........................85 
$\int \sqrt{A} \sqrt{A}\left[\bigcup \begin{array}{l}\text { Journal of Electrical and Electronic Engineering-UMSIDA } \\ \text { ISSN 2460-9250 (print), ISSN 2540-8658 (online) }\end{array}\right.$

Vol. 5, No. 1, April 2021

10.21070/jeeeu.v5i1.1228

Table I. Siklus Pemeliharaan Besar (Overhaul)

\begin{tabular}{|c|c|c|c|c|c|c|c|c|c|c|c|c|c|c|c|c|c|}
\hline UNIT & \multicolumn{5}{|c|}{ SIKLUS 1} & \multicolumn{4}{|c|}{ SIKLUS 2} & \multicolumn{4}{|c|}{ SIKLUS 3} & \multicolumn{4}{|c|}{ SIKLUS 4} \\
\hline PLTU & SI & & AE & SI & SE & SI & ME & SI & SE & SI & ME & SI & SE & SI & ME & SI & SE \\
\hline PLTG & cr & & GPT & cr & MI & Cr & HGPI & CI & $M I$ & CI & HGPT & CI & MI & \begin{tabular}{l|l}
$\mathrm{Cr}$ & $\mathrm{r}$
\end{tabular} & HGPI & cI & MI \\
\hline PLTGU & CI & & $\pi$ & a & MI & a & $\pi$ & ca & MI & cr & $\pi$ & CI & $M I$ & a & $\pi$ & CI & MI \\
\hline PLTGU & \multicolumn{3}{|c|}{ TC/TA } & \multicolumn{2}{|c|}{$\mathrm{TB} / \mathrm{TA}$} & \multicolumn{2}{|c|}{ TC/TA } & \multicolumn{2}{|c|}{$\mathrm{TB} / \mathrm{TA}$} & \multicolumn{2}{|c|}{ TC/TA } & \multicolumn{2}{|c|}{$T B / T A$} & \multicolumn{2}{|c|}{ TC/TA } & \multicolumn{2}{|c|}{$T B / T A$} \\
\hline PLTD & To & & 50 & то & Mo & To & so & то & MO & To & so & To & MO & To & so & To & Mo \\
\hline PLTA & AI & AI & GI & \begin{tabular}{|l|l|} 
AI & AI \\
\end{tabular} & mo & \begin{tabular}{l|l|} 
AI & AI \\
\end{tabular} & \begin{tabular}{|l|l|}
$I$ & GI \\
\end{tabular} & \begin{tabular}{l|l|} 
AI & AI \\
\end{tabular} & мо & \begin{tabular}{l|l} 
AI & AI \\
\end{tabular} & \begin{tabular}{|l|l|}
$x$ & GI \\
\end{tabular} & \begin{tabular}{l|l} 
AI & AI \\
\end{tabular} & mo & \begin{tabular}{|l|l|} 
AI & AII \\
\end{tabular} & GI & \begin{tabular}{l|l} 
AI & AI \\
\end{tabular} & \begin{tabular}{|l|l|}
1 & Mo
\end{tabular} \\
\hline
\end{tabular}


Table II. Usulan Status Unit

\begin{tabular}{|c|c|}
\hline Status & Status \\
\hline 1 & $\begin{array}{l}\text { Baik: Jika Status unit pembangkit dapat mencapai } \\
\text { seluruh target kinerja operasi baik produksi, } \\
\text { penjualan, Equivalent Availability Factor (EAF), } \\
\text { Equivalent Forced Outage Rate (EFOR), } \\
\text { Scheduled Outage Factor (SOF), Sudden Outage } \\
\text { Factor (SdOF) maupun air limpas. }\end{array}$ \\
\hline 2 & $\begin{array}{l}\text { Sedang: Terdapat target kinerja operasi yang tidak } \\
\text { tercapai (Equivalent Availability Factor (EAF), } \\
\text { Equivalent Forced Outage Rate (EFOR), } \\
\text { Scheduled Outage Factor (SOF), Sudden Outage } \\
\text { Factor (SdOF) ) tetapi target produksi tetap } \\
\text { tercapai. }\end{array}$ \\
\hline 3 & $\begin{array}{l}\text { Berat: Jika Target kinerja operasi unit tidak } \\
\text { tercapai dan target produksi tidak tercapai karena } \\
\text { gangguan unit pembangkit. }\end{array}$ \\
\hline
\end{tabular}


Table III. Rekapitulasi Perubahan Status Pembangkit PLTA Ampelgading Unit 1 Saat Dilukan Kebijakan 1

\begin{tabular}{|c|c|c|c|c|c|}
\hline & \multicolumn{5}{|c|}{ Status awal (jumlah bulan) } \\
\hline \multirow{5}{*}{ 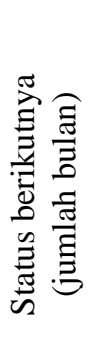 } & & Baik & Sedang & Berat & Jumlah \\
\hline & Baik & 11 & 6 & 0 & 17 \\
\hline & Sedang & 6 & 3 & 0 & 9 \\
\hline & Berat & 0 & 0 & 0 & 0 \\
\hline & Jumlah & 17 & 9 & 0 & 26 \\
\hline
\end{tabular}


Table IV. Rekapitulasi perubahan status pembangkit PLTA Ampelgading unit 1 saat dilakukan kebijakan 2

\begin{tabular}{|c|c|c|c|c|c|}
\hline & \multicolumn{5}{|c|}{ Status awal (jumlah bulan) } \\
\hline \multirow{5}{*}{ 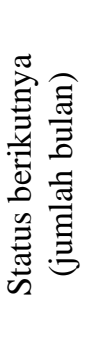 } & & Baik & Sedang & Berat & Jumlah \\
\hline & Baik & 4 & 7 & 0 & 11 \\
\hline & Sedang & 7 & 8 & 0 & 15 \\
\hline & Berat & 0 & 0 & 0 & 0 \\
\hline & Jumlah & 11 & 15 & 0 & 26 \\
\hline
\end{tabular}




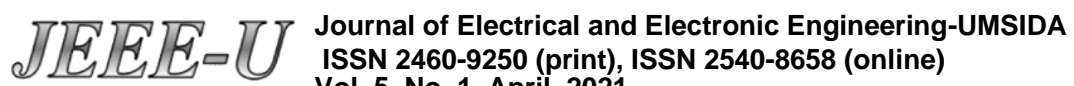

Vol. 5, No. 1, April 2021

10.21070/jeeeu.v5i1.1228

Table V. Rekapitulasi produksi pembangkit PLTA Ampelgading unit 1 saat dilakukan kebijakan 1

\begin{tabular}{|c|c|c|c|c|}
\hline & & \multicolumn{3}{|c|}{ Status awal (KWh) } \\
\hline \multirow{4}{*}{ 志兽高 } & & Baik & Sedang & Berat \\
\hline & Baik & 12.470 .375 & 12.440 .225 & 12.410 .074 \\
\hline & Sedang & 0 & 12.425 .149 & 12.425 .149 \\
\hline & Berat & 0 & 0 & $12.334,697$ \\
\hline
\end{tabular}


$\left.\int\right]\left[\begin{array}{l}G \\ 0\end{array}\right] \begin{aligned} & \text { Journal of Electrical and Electronic Engineering-UMSIDA } \\ & \text { ISSN 2460-9250 (print), ISSN 2540-8658 (online) }\end{aligned}$

Vol. 5, No. 1, April 202

$10.21070 /$ jeeeu.v5i1.1228

Table VI. Rekapitulasi produksi pembangkit PLTA Ampelgading unit 1 saat dilakukan kebijakan 2

\begin{tabular}{|c|c|c|c|c|}
\hline & & \multicolumn{3}{|c|}{ Status awal (KWh) } \\
\hline \multirow{4}{*}{ 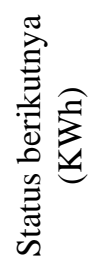 } & & Baik & Sedang & Berat \\
\hline & Baik & 12.545 .752 & 12.545 .752 & 12.545 .752 \\
\hline & Sedang & 12.169 .380 & 11.918 .465 & 11.918 .465 \\
\hline & Berat & 10.036 .602 & 11.291 .177 & 10.036 .602 \\
\hline
\end{tabular}


Table VII. Tabel perbandingan produksi hasil perhitungan

\begin{tabular}{|c|c|c|c|c|c|}
\hline No & Unit & $\begin{array}{c}\text { Produksi } \\
\text { Markov } \\
(\mathrm{GWh}) \\
\mathrm{A}\end{array}$ & $\begin{array}{c}\text { Produksi } \\
2019 \\
(\mathrm{GWh}) \\
\mathrm{B}\end{array}$ & $\begin{array}{c}\text { Produksi } \\
2018 \\
(\mathrm{GWh}) \\
\mathrm{C}\end{array}$ & $\begin{array}{c}\text { Produksi } \\
2017 \\
(\mathrm{GWh}) \\
(\mathrm{D})\end{array}$ \\
\hline 1 & Ampelgading & 36 & 25 & 30 & 33 \\
\hline 2 & Giringan & 14 & 10 & 12 & 15 \\
\hline 3 & Golang & 13 & 9 & 11 & 14 \\
\hline 4 & Lodoyo & 38 & 34 & 37 & 38 \\
\hline 5 & Mendalan & 75 & 76 & 78 & 79 \\
\hline 6 & Ngebel & 13 & 8 & 9 & 13 \\
\hline 7 & Selorejo & 30 & 22 & 26 & 30 \\
\hline 8 & Sengguruh & 79 & 66 & 75 & 97 \\
\hline 9 & Siman & 46 & 52 & 56 & 44 \\
\hline 10 & Sutami & 572 & 410 & 486 & 589 \\
\hline 11 & Tulungagung & 155 & 87 & 117 & 155 \\
\hline 12 & Wlingi & 193 & 129 & 154 & 200 \\
\hline 13 & Wonorejo & 33 & 17 & 19 & 31 \\
\hline \multicolumn{7}{|c|}{ TOTAL } & 1.303 & 951 & 1.114 & 1.303 \\
\hline
\end{tabular}


Table VIII. Perbandingan Capaian Biaya Pokok Penyediaan Markov vs Capaian Biaya Pokok Penyediaan Aktual

\begin{tabular}{|c|c|c|c|c|}
\hline Unit & $\begin{array}{c}\text { BPP } \\
\text { Markov } \\
(\mathrm{Rp} / \mathrm{KWh})\end{array}$ & $\begin{array}{c}\text { BPP } \\
2019 \\
(\mathrm{Rp} / \mathrm{KWh})\end{array}$ & $\begin{array}{c}\text { BPP } \\
2018 \\
(\mathrm{Rp} / \mathrm{KWh})\end{array}$ & $\begin{array}{c}\text { BPP } \\
2017 \\
(\mathrm{Rp} / \mathrm{KWh})\end{array}$ \\
\hline Ampelgading & 352 & 269 & 357 & 392 \\
\hline Giringan & 780 & 738 & 633 & 768 \\
\hline Golang & 745 & 615 & 504 & 712 \\
\hline Lodoyo & 382 & 274 & 388 & 384 \\
\hline Mendalan & 583 & 479 & 541 & 576 \\
\hline Ngebel & 634 & 973 & 651 & 644 \\
\hline Selorejo & 388 & 377 & 505 & 392 \\
\hline Sengguruh & 574 & 360 & 720 & 480 \\
\hline Siman & 564 & 320 & 365 & 592 \\
\hline Sutami & 293 & 323 & 294 & 283 \\
\hline Tulungagung & 481 & 619 & 512 & 487 \\
\hline Wlingi & 366 & 457 & 409 & 360 \\
\hline Wonorejo & 392 & 580 & 458 & 413 \\
\hline
\end{tabular}


$\int \sqrt{G} \sqrt{G} \sqrt{G}\left[\int \begin{array}{l}\text { Journal of Electrical and Electronic Engineering-UMSIDA } \\ \text { ISSN 2460-9250 (print), ISSN 2540-8658 (online) }\end{array}\right.$

Vol. 5, No. 1, April 2021

\section{DAFTAR GAMBAR}

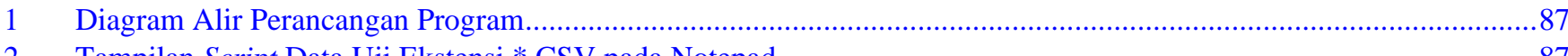

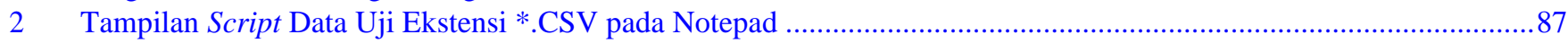

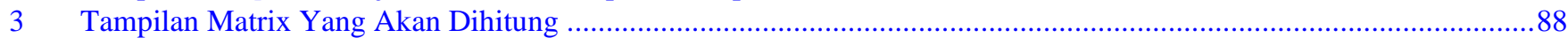

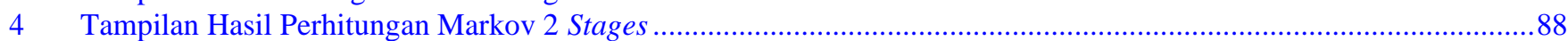

$5 \quad$ Grafik Perbandingan Produksi dan BPP PLTA 2017, 2018, 2019 dan Markov ............................................................8 


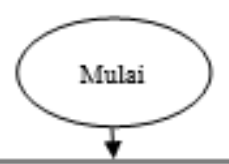

Memasukkan data:

1. Pilih Unit Pembangkit

2. Status Pembangkit pada kebijakan 1

3. Status Pembangkit pada kebijakan 2

4. Produksi pembangkit pada kebijakan 1

\section{$\downarrow$}

Pembacaan data dan perhitungan probabilitas pada kebijakan 1 , probabilitas transisi kebijakan 2 , probabilitas produksi kebijakan 2

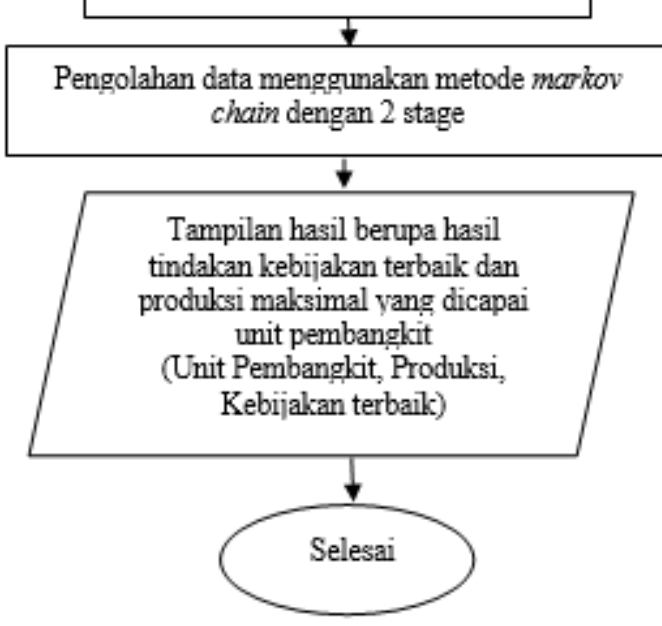

Figure 1. Diagram Alir Perancangan Program

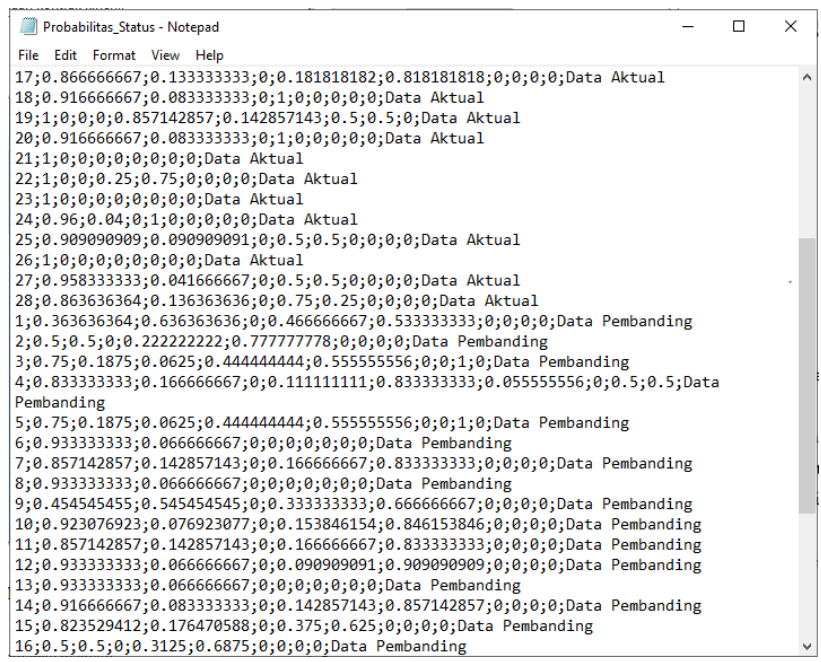

Figure 2. Tampilan Script Data Uji Ekstensi *.CSV pada Notepad 


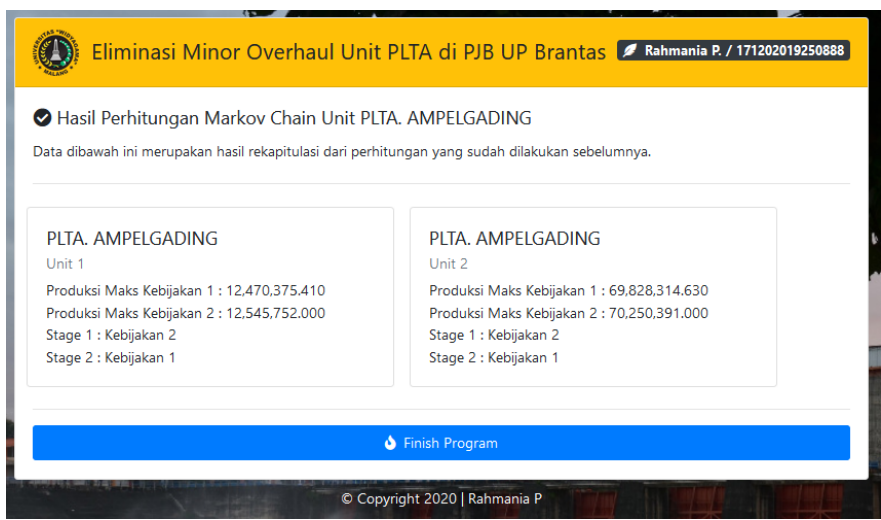

Figure 3. Tampilan Matrix Yang Akan Dihitung

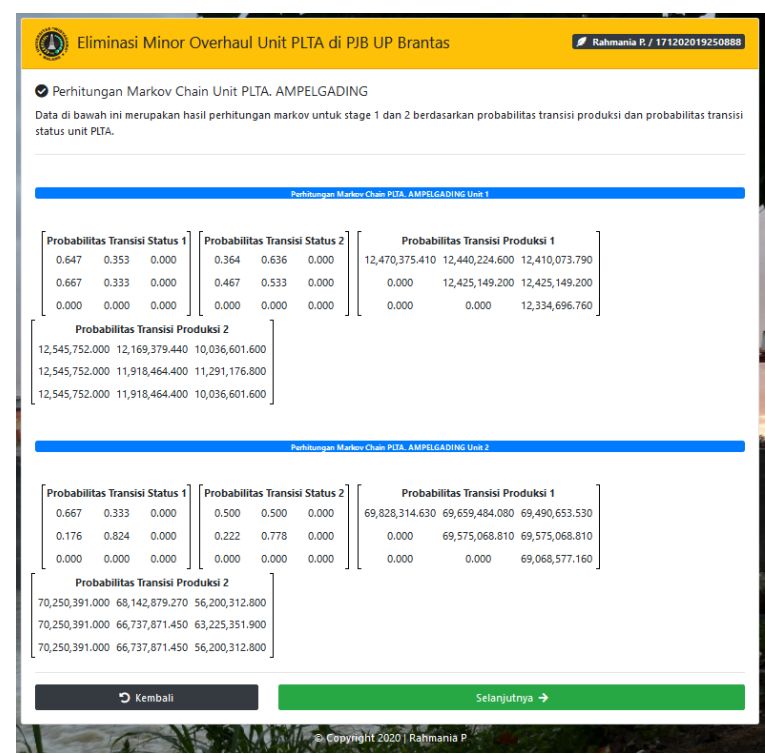

Figure 4. Tampilan Hasil Perhitungan Markov 2 Stages

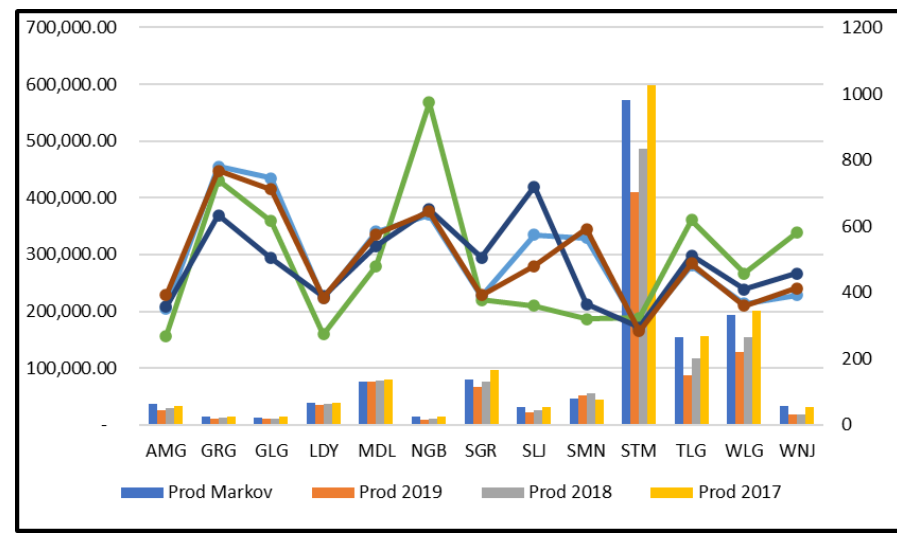

Figure 5. Grafik Perbandingan Produksi dan BPP PLTA 2017, 2018, 2019 dan Markov 